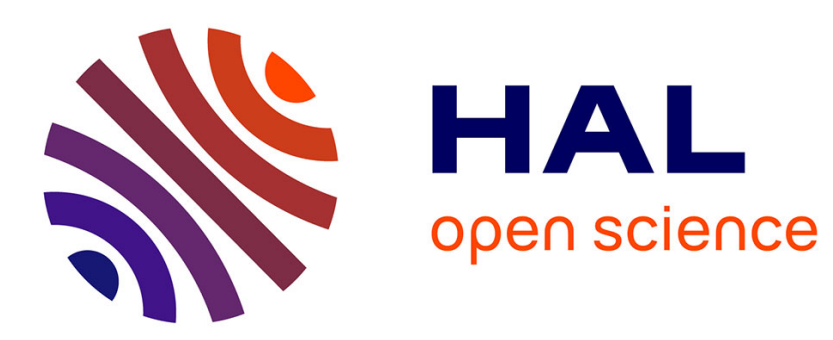

\title{
Rome Redeems Athens? Livy, the Peloponnesian War, and the Conquest of Greece
}

\author{
David S. Levene
}

\section{To cite this version:}

David S. Levene. Rome Redeems Athens? Livy, the Peloponnesian War, and the Conquest of Greece. KTÈMA Civilisations de l'Orient, de la Grèce et de Rome antiques, 2017, 42, pp.73-84. halshs01669255

\section{HAL Id: halshs-01669255 \\ https://shs.hal.science/halshs-01669255}

Submitted on 21 Dec 2017

HAL is a multi-disciplinary open access archive for the deposit and dissemination of scientific research documents, whether they are published or not. The documents may come from teaching and research institutions in France or abroad, or from public or private research centers.
L'archive ouverte pluridisciplinaire HAL, est destinée au dépôt et à la diffusion de documents scientifiques de niveau recherche, publiés ou non, émanant des établissements d'enseignement et de recherche français ou étrangers, des laboratoires publics ou privés. 

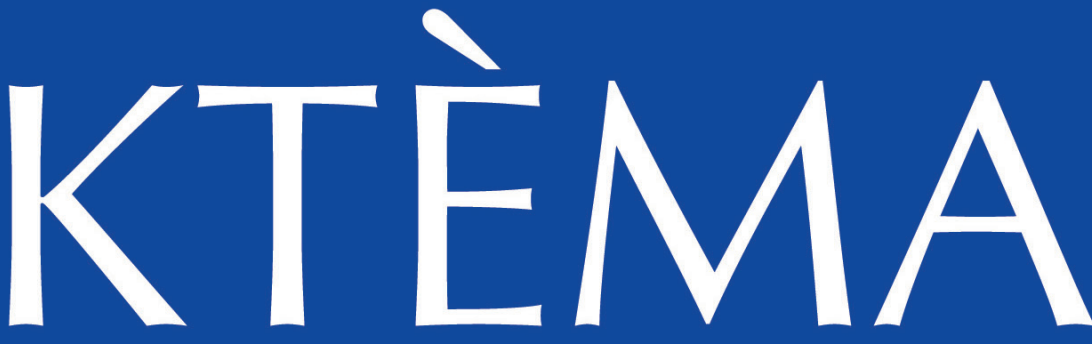

\section{CIVILISATIONS DE L'ORIENT, DE LA GRÈCE ET DE ROME ANTIQUES}

Edith Foster

Edmond LÉvY

Tim Roop

Cinzia Bearzot

\section{Michel Нumm}

David S. Levene

Estelle OudoT

Hans Kopp

Maciej JUNKIERT

Tobias Јоно

Christian WENDT

Oliver SCHELSKe

Dominique Lenfant

Neville MORLEY

Agnès Molinier Arbo

Michèle Coltelloni-Trannoy Philippe Torrens

Jean Ducat

Michel WoronofF

\section{Les interprétations de la défaite de 404}

Interpretations of Athen's defeat in the Peloponnesian war............................................................ 7

Thucydide, le premier interprète d'une défaite anormale .............................................................. 9

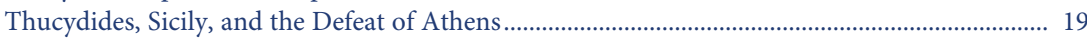

La $\sigma u \mu \varphi$ ód de la cité

La défaite d'Athènes (405-404 av. J.-C.) chez les orateurs attiques.............................................. 41

Rome, une «cité grecque» prise par les Hyperboréens.................................................................... 53

Rome Redeems Athens?

Livy, the Peloponnesian War, and the Conquest of Greece............................................................ 73

Ultime défaite d'Athènes ou sa plus belle victoire?

Stratégies rhétoriques autour de la bataille d'Aigos-Potamoi

dans le Panathénaïque d'Aelius Aristide

The Defeat of Athens in 404 BC in The Federalist ............................................................................ 97

Polish Reflections: The Reception of the Defeat of Athens in

the Works of Gottfried Ernst Groddeck and Joachim Lelewel.........................................................115

The Internal Commotion of Greek Culture: Jacob Burckhardt

on the Defeat of Athens in the Peloponnesian War.

Spree-Athen nach dem Untergang

Eduard Meyer zur Parallelität von Geschichte

Der Kampf um die Demokratie

Thukydides in Deutschland nach dem Ersten Weltkrieg

Défaite militaire et révolution antidémocratique

Le parallèle entre l'Athènes de 404 et la France de 1940

dans Les Oligarques de Jules Isaac.

Thucydides and the Historiography of Trauma.

\section{Le thauma dans l'historiographie grecque d'époque impériale}

Hérodien, Rome et le spectacle du pouvoir

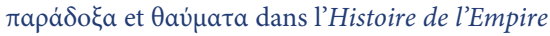

après la mort de Marc Aurèle

La place du thauma dans l'Histoire romaine de Cassius Dion............................................................219

Le lexique de l'étonnement chez Appien. Quelques remarques .......................................................23

\section{Varia}

Du caractère «mixte» du régime spartiate 251

L’image de la défaite dans l'Iliade. 


\author{
KTÈMA \\ CIVILISATIONS DE L'ORIENT, DE LA GRÈCE ET DE ROME ANTIQUES \\ Revue annuelle \\ Fondateurs : Edmond Frézouls † \\ Edmond LÉvY
}

Comité Directeur: Dominique Beyer, Bruno Bleckmann, Jean-François Bommelaer, Frédéric Colin, MireilleCorbier, GérardFreyburger, Jean Gascou, Jean-Georges Heintz, Michel Humbert, Anne Jacquemin, Stavros Lazaris, Dominique Lenfant, Edmond Lévy, Jean-Claude Margueron, Henriette Pavis d'Escurac, Laurent Pernot, Thierry Petit, Gérard SiEBERT

Rédaction:Edmond LÉvy

Dominique Beyer et Gérard Freyburger

Maquette et mise en page: Ersie LERIA

\title{
Éditeur
}

Presses universitaires de Strasbourg

5 allée du Général Rouvillois - CS50008

FR-67083 Strasbourg Cedex

Tél: (33) 0368856265

info.pus@unistra.fr

pus.unistra.fr

\section{Ventes au numéro}

En librairie ou en commande en ligne sur le site du Comptoir des presses d'universités: www.lcdpu.fr

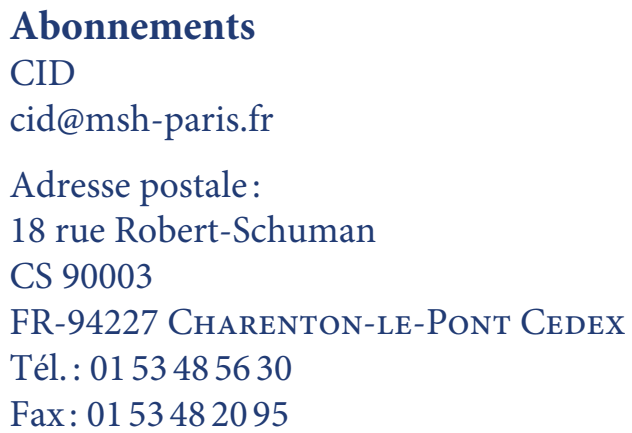




\section{Rome Redeems Athens? Livy, the Peloponnesian War, and the Conquest of Greece}

RÉsumé-. Quand Tite-Live raconte les guerres entreprises par Rome en Grèce au début du II ${ }^{\mathrm{e}}$ siècle av. J.-C., il n'ignore jamais les faits saillants de l'histoire antérieure des États qui passent sous la domination de Rome. La guerre du Péloponnèse constitue une part importante de cette histoire. Tite-Live fait en passant allusion à cette guerre lorsque Rome (à la demande d'Athènes) prend les armes contre Philippe V de Macédoine; mais la guerre du Péloponnèse joue un rôle encore plus important quand il décrit les guerres contre Sparte, et la défaite de celle-ci d'abord devant les Romains, puis devant le général achaïen Philopoemen. Au moyen d'allusions au récit de Xénophon sur la défaite athénienne, Tite-Live indique que les Spartiates subissent maintenant un sort semblable à celui qu'ils avaient infligé aux Athéniens.

Abstract-. When Livy describes Rome's wars in Greece at the beginning of the 2nd century B.C., he does so in constant awareness of the distinguished prior history of those states who are falling under Roman sway. A significant part of that history is the Peloponnesian War. Livy alludes in passing to the war when Rome (at the request of Athens) takes up arms against Philip V of Macedon; but the Peloponnesian War plays a still more important role in his accounts of the wars against Sparta, and its defeat first by the Romans and subsequently by the Achaean general Philopoemen. Through allusions to Xenophon's account of the Spartan defeat of Athens, Livy indicates that the Spartans now are suffering a similar fate to that which they inflicted on the Athenians.

Livy alludes a number of times in his surviving books to Thucydides' and (less often) Xenophon's histories. Most of these allusions do not indicate any particular attitude to the Peloponnesian War on Livy's part: instead he is responding intertextually to aspects of the Greek historians' works which are not specific to the war. ${ }^{1}$ Quite apart from allusions of this sort, however, there are some indications that the Peloponnesian War of itself carried broader ideological significance to Livy. In the surviving books, there are three explicit references to it. All of these relate to the Sicilian expedition. The first comes in 25.24.12: Marcellus, surveying Syracuse on the point of its capture, recalls 'the Athenian fleets sunk and the two vast armies with their two very famous generals destroyed' (Atheniensium classes demersae et duo ingentes exercitus cum duobus clarissimis ducibus deleti)-an obvious but potent image, with overtones not only of the reversal of fortune for the Syracusans themselves, but also, implicitly, a contrast between the imminent Roman success and

(1) For two examples from Book 45, the last surviving book of the history, see 45.23.14-16, alluding to ThUCYDIDES 1.70.2-4, and 45.28.4, alluding to Thucydides 1.10.2; on the implications of the Thucydidean imitation in the second passage, see esp. LEVENE 2006, p. 77-87. 
the Athenian failure. ${ }^{2}$ This is not, of course, to suggest that there are no uncomfortable overtones for Rome herself: in particular, reflections on the fall of an enemy city can often also indicate the fragility of one's own good fortune, a theme which is played out in the case of Marcellus by an awareness of the extent to which Rome's conquest of Syracuse will mark a stage in her moral decline. ${ }^{3}$ But this does not exclude the Athenian parallel: their attack on Syracuse bears more than a slight resemblance to Marcellus' own, and the marked difference in the outcome is apparent.

This point emerges even more directly from the other references to the Sicilian Expedition in Livy: in Book 28, during the debate between Fabius and Scipio on Scipio's proposed plan to take the war to the Carthaginians by launching an invasion of Africa. ${ }^{4}$ Fabius warns Scipio against the invasion, referring to the precedent of the Sicilian expedition and the disaster that resulted (28.41.17):

Athenienses, prudentissima civitas, bello domi relicto, auctore aeque impigro ac nobili iuvene, magna classe in Siciliam tramissa, una pugna navali florentem rem publicam suam in perpetuum adflixerunt. The Athenians, a most sensible country, abandoning the war at home, under the promptings of a young man who was no less vigorous than noble, sent a vast fleet across to Sicily, and in a single naval battle damaged forever their own state which was then at its peak.

In response, however, Scipio deflects the argument by offering what he suggests is a better example, namely that of the Syracusan Agathocles' counterattack on Africa when he was under pressure from the Carthaginians in Sicily (28.43.20-21):

at etiam Athenienses audiendi sunt temere in Siciliam omisso domi bello transgressi. cur ergo, quoniam Graecas fabulas enarrare vacat, non Agathoclem potius Syracusanum regem, cum diu Sicilia Punico bello ureretur, transgressum in hanc eandem Africam avertisse eo bellum unde venerat refers? But we have to hear about the Athenians, who rashly crossed into Sicily, abandoning the war at home. So why, since you have time to recount Greek stories, do you not instead tell about Agathocles, the king of Syracuse, who, when Sicily was long burning with a Carthaginian war, by crossing over to the same place, Africa, directed the war back to the place from which it originated?

This brief exchange has many ramifications. In particular, the comparison which Fabius makes between the Sicilian Expedition and the invasion of Africa signals to the reader a wider comparison: the debate he holds with Scipio mirrors the famous debate on the Sicilian Expedition between Nicias and Alcibiades. Various scholars have detected allusions to Thucydides' version of that debate (6.8-26) in the speeches in Livy; ${ }^{5}$ however, I have argued that, although Thucydides is certainly relevant, the speech of Fabius is closer to the version of Nicias' speech in Diodorus Siculus 12.83.6 than to Thucydides' version, suggesting that Livy is primarily alluding to Diodorus' source, who was probably Ephorus; along similar lines, Scipio's speech is likewise much closer to Diodorus' account of Agathocles' rationale for invading Africa (20.3.3) than to anything Thucydides attributes to Alcibiades-Scipio's argument is thus signaling that his speech depends, not on Thucydides or any other historian of the Peloponnesian War, but on one of the historians of Agathocles, probably Duris of Samos or Timaeus. ${ }^{6}$ But either way, when it comes to the Peloponnesian War, the upshot of the argument is clear. With all of these allusions, the Romans are identified with Athens, yet with that identification it is as much the contrast between Athens and Rome as the similarities that comes to the fore. Rome, as demonstrated by her victories during the Second Punic War, has the capacity to succeed where Athens did not.

(2) On this see e.g. Rossi 2000, Marincola 2005; more broadly JaEger 2010.

(3) See Rossi 2000, p. 60-63; MARincola 2005, p. 225-226.

(4) On the Sicilian Expedition in the Fabius-Scipio debate, see also Roon's paper in this volume.

(5) First suggested by StÜBler 1941, p. 157-158; for wider discussion see Rodgers 1986, Polleichtner 2010.

(6) LEVENe 2010, p. 111-118. 
With this in mind, it is worth now turning to consider the war which immediately succeeds the Second Punic War in Livy, namely the Second Macedonian War, the war that for Livy marks Rome's first large-scale incursion into mainland Greece (he had treated the First Macedonian War as effectively an appendage to the Second Punic War). It would not be especially surprising if he had seen a connection between that Roman incursion and one of the most famous wars of mainland Greece, a war documented by some of the best-known writers in Greek literary history, and a war to which he had directly alluded more than once in his work in the books prior to the war beginning.

It is admittedly hard to detect direct allusions to the texts of Thucydides or Xenophon on the Peloponnesian War in the passages that introduce the Second Macedonian War. But the absence of allusions that are recognizable to us should not preclude the possibility that Livy signaled the salience of the Peloponnesian War in ways that members of his original audience might have recognized. One possibility has already been mentioned (above, p. 70): that Livy might have referred to the Peloponnesian War not via an allusion to Thucydides or Xenophon, but via an allusion to another historian of the war who was widely read in his own day, such as Ephorus. A second possibility is that he alludes to a source, most probably Polybius, who had himself quoted Thucydides or Xenophon, and Livy signals an allusion to them via his imitation of Polybius, even though his specific wording may not be adequate to mark a reference to those authors independently of the fact that his source quoted them. ${ }^{7}$ But there is a third possibility also: that the salience of the Peloponnesian War to Livy may be marked, not by any specific references to the events of that war, but rather through the broader presence of Athens and Sparta in the narrative as Rome comes to conquer Greece, and the fact that Rome is in various ways interacting with the roles that they played in the classical period in general, including during the time of the Peloponnesian War. ${ }^{8}$ Athens and Sparta are in different ways central to Livy's image of the conquest of Greece, but what they share is a sense that each has declined from its classical peak; it is Rome who will now occupy the position of power in Greece. Part of Livy's object in Books 31-45 is to document that reversal, and it is as much in that, as in any specific allusions, that the Peloponnesian War becomes relevant to Livy.

With that said, it should be made clear that while the Peloponnesian War is indeed for Livy an important part of the Greek background to the Roman conquest (and I shall suggest some specific reasons below why we should think that is the case), there is no reason to think that it loomed as large in Livy's image of the Greek past as it does in ours. Thucydides and Xenophon were important authors, but they were not for Romans of Livy's day as exceptional as they appear today as representatives of classical Greek historiography, nor was the war they recounted so central a highlight of Greek history. ${ }^{9}$ At most we can say that the consciousness of the Peloponnesian War fades in and out, ${ }^{10}$ as allusions are introduced to texts concerned with that war, or descriptions of events that appear to recall the events of that war. But other parts of Greek history matter as well; for example, it is likely that for at least some Roman readers, faced with the picture of the Macedonian Philip V seeking to exert control over mainland Greece, the parallels that would first be called to mind would be with the earlier Philip who had originally established Macedonian hegemony in

(7) For a specific example of this with Xenophon, see Levene 2010, p. 92-95.

(8) For the broader theory underlying this, see LEVENe 2015, p. 210-215: I argue there that the unique ontological status of historiography - the historian's commitment to a representation of an external reality-implies that meaningful allusions in historiography may arise simply from parallels which the historian knows will be apparent to his readers, even if he does not make any material alterations to the events or any attempt to mark the allusions with specific linguistic features designed to recall another text.

(9) In this respect, Livy's perceptions may not have been inaccurate: cf. PRITCHARD 2015.

(10) Cf. Levene 2010, p. 106-107. 
that region in the 4th century B.C. ${ }^{11}$ Admittedly, recognition of that parallel would inevitably be accompanied by a recognition of one factor that massively changed the circumstances from those that the Athenians were faced with after the victory of Philip II at Chaeronea: the potential for Rome to intervene against him. In 200 the Athenians could and did appeal to Rome for assistance, and indeed, for Livy, it was primarily at the behest of the Athenians that the Romans were drawn into war with Philip in the first place. ${ }^{12}$

The parallel between the situation in 4th century Greece and the Second Macedonian War, and the differentiation created by the involvement of Rome in the latter, do not only rest in the name of the monarch involved: Livy marks it considerably more directly. One allusion that draws attention to the parallel occurs in the arguments used by the Roman consul P. Sulpicius Galba, in his speech to a contio recommending war with Philip after the assembly had originally voted against it (31.7.2): ignorare ... mihi videmini, Quirites, non utrum bellum an pacem habeatis vos consuli-neque enim liberum id vobis Philippus permittet, qui terra marique ingens bellum molitur-sed utrum in Macedoniam legiones transportetis an hostes in Italiam accipiatis.

You seem to me not to be aware, citizens, that the decision you are making is not whether to have war or peace-for Philip will not leave you free to make that choice, since he is preparing a vast war on land and sea-but whether you take your legions across to Macedonia or receive enemies in Italy.

This passage has been the subject of heated debate: in particular, whether the Romans began the war because they feared, and even perhaps had reason to fear that, if unchecked in Greece, Philip might launch an invasion across the Adriatic. ${ }^{13}$ Whether or not that is the case, it is generally accepted that the specific details of Sulpicius' speech are invented, even if the basic motif of fear was an argument he actually invoked. What is less commonly noted in this context, however, is that the arguments derive from Demosthenes, Philippics 3.7:

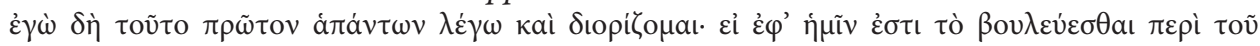

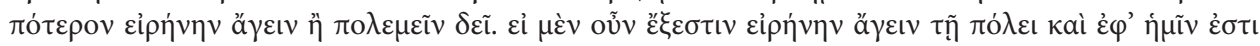

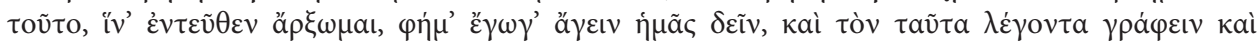

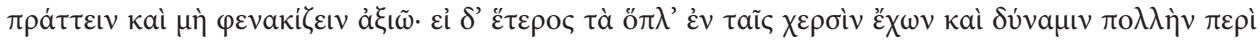

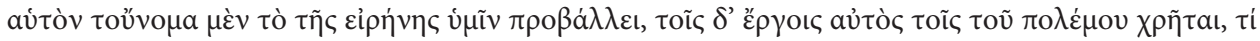

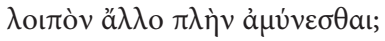

I first of all state and define this question-whether it is in our power to discuss whether we must make war or peace act. If indeed Athens can remain at peace and if the choice rests with us - to take that point first-I personally feel that we are bound to do so; and if anyone says that we can, I call upon him to move a resolution and to do something and to play us no tricks; but if there is another person concerned, with sword in hand and a mighty force at his back, who imposes on you with the name of peace but himself indulges in acts of war, what is left but to defend ourselves?

Despite the fact there are no clear linguistic overlaps (though cf. above), the combination of the parallelisms in the overall situation (noted above) with the specifics of the argument are sufficient to recall Demosthenes here. Rome is, according to this argument, faced with the same dilemma

(11) It is possible that Livy is reflecting a comparison which was signaled more directly in the parallel passages of Polybius, who had earlier compared (to the disadvantage of the latter) Philip II after Chaeronea with Philip V (5.10.1-5; cf. 18.14.13-14, 22.16).

(12) Cf. Livy 31.1.10: preces Atheniensium, quos agro pervastato in urbem compulerat, excitaverunt ad renovandum bellum-'The Romans were provoked to renew the war by the entreaties of the Athenians, whom Philip had driven into their city after devastating their territory'.

(13) For two strongly contrasting views on this question, see HARRIs 1979, p. 212-218, who largely discounts fear as a motive (though he does accept, at least in principle, that Sulpicius might have used these arguments (HARRIs 1979, p. 214)), and ECKSTEIN 2006, p. 269-280 (also ECKSTEIN 2008, p. 253-265), who suggests that not only were some such arguments as these likely to have been made, but also that they would have seemed plausible to the Romans, and as such a major influence on their decision to go to war. 
as Athens had been; and the Romans respond with immediate recourse to war. But while this might appear to mark a similarity between Rome and Athens, a later allusion to Demosthenes draws attention to the differences between them. Livy, recording the decrees that Athens passed dishonouring Philip, comments in his own voice Athenienses quidem litteris verbisque, quibus solis valent, bellum adversus Philippum gerebant (31.44.9: 'The Athenians indeed waged war against Philip with letters and words, the only things in which they are powerful'). The present tense in valent is noteworthy: Livy is not only making a comment about the lack of Athenian power at the time of Philip, but is generalizing more broadly about their national character up to and including

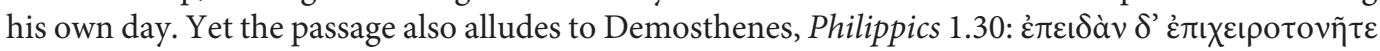

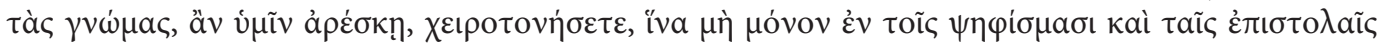

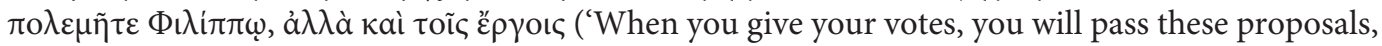
if you approve them, in order to fight Philip not only in decrees and letters, but also with deeds'). ${ }^{14}$ Demosthenes wished Athens to go beyond mere words in confronting their enemies: Livy shows them as having become constitutionally unable to do so.

Livy is indeed explicit that Athens, in her opposition to Philip, had declined badly from the power that she had possessed at her height. ${ }^{15}$ When noting the atrocity which was the casus belli between Athens and Macedon (the murder of two of Philip's allies who had accidentally committed a sacrilege), he remarks: contraxerant autem sibi cum Philippo Athenienses bellum haudquaquam digna causa, dum ex vetere fortuna nihil praeter animos servant (31.14.6: 'But the Athenians had embarked on a war with Philip for a far from worthy reason, while they retained nothing except their spirit from their old fortune'). The comment on Athenian decline is pointed: while it might appear that retaining their former animos is at least some consolation for the loss of military and political power, the Athenian animus, whether in the past or in the present, was not uniformly virtuous, as indeed their actions here suggest. ${ }^{16} \mathrm{~A}$ key part of the Athenian 'spirit' in classical times was thought to be susceptibility to demagogy, and this, too, Livy indicates to be a fundamental aspect of their character. The decrees passed against Philip (above) are preceded by a sardonic generalization about the particular problem Athens had in this regard (31.44.2-3):

tum vero Atheniensium civitas, cui odio in Philippum per metum iam diu moderata erat, id omne in auxilii praesentis spem effundit. nec unquam ibi desunt linguae promptae ad plebem concitandam; quod genus cum in omnibus liberis civitatibus tum praecipue Athenis, ubi oratio plurimum pollet, favore multitudinis alitur.

(14) The parallel is noted by BRISCOE 1973, p. 152, who suggests that Livy derived it from Polybius.

(15) BRISCOE 1973, p. 95 attributes the hostile image of Athens in these passages to Polybius, citing as parallels PoLYBIUS 5.106.6-8, 6.43-4, 9.23, and 30.20. However, even if Livy did indeed find comparable judgements at this point in Polybius (which is less certain than Briscoe asserts), he was by no means obliged to transmit them, and that he did so is significant for his own understanding of the Greek past.

(16) It may be relevant in this context to note a much-discussed problem in Livy's account: that when describing immediately after this the vote of the Athenians to go to war with Philip (31.15), he mentions that they did so with the active support and encouragement of Attalus of Pergamon and the Rhodians, but he does not mention the presence of and support given by a Roman embassy, which is referred to in the parallel passage of Polybius (16.25.1-3; cf. 16.26.6, 16.27.1). Various arguments have been canvassed of greater or lesser complexity: for example, that Livy found himself in chronological problems concerning the date at which the Romans determined on war (so BRISCOE 1973, p. 41-7), or that Livy when attempting to match up his different sources was confused about the identity of the ambassadors, so preferred to omit them (LUCE 1977, p. 67-73), or that it is a structural decision made by Livy in order to avoid prolonging his account of the consular year 201, to which the account of the embassy belonged (WARRIOR 1996, p. 30-31). It may be that more than one of these has some measure of truth to it; we do not need to assume that the omission had a single cause. However, it is worth adding into the mix this hostile portrait of the Athenians' provocation against Philip, especially if we do not regard it as necessarily derived from Polybius (n. 15); that would provide an additional reason for Livy not to show direct Roman instigation or support behind their move to war. 
Then indeed the Athenians' state, whose hatred against Philip had for a long time been tempered by fear, poured it all out in hope of immediate help. There are never lacking in that place tongues ready to arouse the people, a type which is present in all free states but in Athens above all, where oratory has the greatest power, and it is nourished by the support of the masses.

The easy slide between Athenian democracy and Athenian demagogy was commonly remarked on by writers of the classical period, Thucydides not least. ${ }^{17}$ Livy aligns his own narrative with the traditions of Athenian history and Athenian history writing.

All of this points to Livy's interest in Athenian history, and indeed once again to his implicit identification of Rome and Athens, but not specifically to the Peloponnesian War. The latter is, however, hinted at when Philip attacks Athens: a Piraeo Athenas repente duxit. inde eruptione subita peditum equitumque inter angustias semiruti muri qui bracchiis duobus Piraeum Athenis iungit repulsus (31.26.7-8: 'Philip suddenly marched from the Piraeus to Athens; but he was driven back by a sudden sally of infantry and cavalry between the narrow spaces of the half-destroyed wall which joins the Piraeus to Athens with two branches'). The Long Walls, destroyed by the Spartans under Lysander at the end of the Peloponnesian War (cf. below), had been rebuilt under the leadership of Conon in the 390s (Xen., Hell. 4.8.9-10, Diod. Sic. 14.85.2-3; cf. Rhodes-Osborne, GHI no.9). When Livy refers to them here as semiruti, he is usually assumed to be indicating their delapidation by the end of the third century B.C. ${ }^{18}$ But there is no other evidence for this: Livy makes no reference to delapidation when he describes Aemilius Paullus seeing them a generation later at 45.27.11, and the adjective would more naturally refer to active destruction than collapse through neglect-yet there was no destruction of the walls between the time of Lysander and that by Sulla in 89 (Strabo 9.1.15). It is more likely that semiruti alludes to the fact that there were originally three walls, but only two were rebuilt by Conon: certainly, for the reader who remembered Athenian history, the description could hardly fail to evoke the destruction at the hands of the Spartans. The walls were destroyed by the Spartans; but their rebuilding was only partial, and this carries a significant implication for Livy's view of the Athenian past. As noted above (p. 71-72), Livy's allusions to the conquest of Greece by Philip II highlight the contrast between Athens and Rome: the Romans are an effective and rising power who are well able to confront Philip V; the Athenians at the time of Demosthenes were unable to mount a comparably effective opposition to Philip II. This passage indicates the reason: even in the 4 th century, Athens was no longer what she had been in the 5th century. The defeat in the Peloponnesian War was something from which the city never truly recovered.

Accordingly, from the arguments presented here, Livy's account of the Romans' initial move into Greece in the Second Macedonian War has as part of its background a certain memory of the Peloponnesian War. That memory is muted, and to some extent overridden, by the more salient background of Philip II's defeat of Athens a couple of generations later-yet Livy's allusions to the Peloponnesian War suggest that it was the defeat at the hands of Sparta which made the victory of Philip II possible.

The Peloponnesian War does, moreover, become a more acute presence a few years (and Livian books) later, when Sparta enters the picture and the Romans take up arms against the then ruler of Sparta, Nabis. Here too, as with Philip V, it is the Athenians who take the lead in pushing the Romans to war (Livy 34.23.2-5):

cum legatus Atheniensium quantum poterat gratiis agendis Romanorum in Graeciam merita extulisset-imploratos adversus Philippum tulisse opem, non rogatos ultro adversus tyrannum Nabim

(17) Most famously at 2.65.7-10; cf. also e.g. [Aristotle], Ath. Pol. 28.3-4. On 'demagogy' as a political phenomenon in classical Athens, see FINLEY 1962.

(18) So e.g. Judeich 1905, p. 89. 
offerre auxilium-indignatusque esset haec tanta merita sermonibus tamen aliquorum carpi futura calumniantium, cum fateri potius praeteritorum gratiam deberent, apparebat incessi Aetolos. igitur Alexander princeps gentis, invectus primum in Athenienses, libertatis quondam duces et auctores, adsentationis propriae gratia communem causam prodentes.

The envoy of the Athenians in proposing thanks extolled to the utmost degree the services of the Romans towards Greece: when they were appealed to they had helped against Philip, and now they were spontaneously without being asked offering help against the tyrant Nabis. When he complained that these great services were being criticized in the talk of some who were slandering things that were going to happen when they should rather be expressing gratitude for what had been done, he was clearly attacking the Aetolians. Therefore Alexander, the Aetolian leader, first attacked the Athenians, erstwhile leaders and promoters of freedom, who now were betraying the common cause out of self-seeking obsequiousness.

Setting the Athenians as the primary opponents of the Spartans is liable to evoke the most famous war between those two states; however, the acid comment by the Aetolians that the Athenians are betraying their own history evokes that war in a different way. At an earlier period, notably that of the Persian Wars, the Athenians might have been able to proclaim themselves as promoters of freedom; but in the Peloponnesian War, at least in Thucydides' presentation, it was the Spartans who had taken up that mantle, and the Athenians, as here, were accused of having betrayed the cause of freedom. ${ }^{19}$ Now, however, the role has been taken over by Rome, not least because of Flamininus' famously ostentatious proclamation of Greek freedom at the Isthmian Games in Livy's previous book (33.32).

The echoes of the Peloponnesian War, however, do not leave even the Romans wholly uncompromised. Their ostensible aim, as they explain shortly afterwards, is, as liberators of Greece, to depose the tyrant Nabis and to restore Sparta to the Lycurgan constitution (Livy 34.32.4-5):

nobis vero, etiamsi Argos nec cepisses per fraudem nec teneres, liberantibus omnem Graeciam Lacedaemon quoque vindicanda in antiquam libertatem erat atque in leges suas, quarum modo tamquam aemulus Lycurgi mentionem fecisti. an ut ab Iaso et Bargyliis praesidia Philippi deducantur curae erit nobis, Argos et Lacedaemonem, duas clarissimas urbes, lumina quondam Graeciae, sub pedibus tuis relinquemus quae titulum nobis liberatae Graeciae servientes deforment?

Even if you had not taken Argos by deceit and were not holding it, we are the liberators of all of Greece, and were obliged to free Sparta also and return it to its former liberty and its own laws, which you mentioned just now as if you were the rival of Lycurgus. Are we to ensure that Philip's garrisons are withdrawn from Iasus and Bargyliae, and leave under your feet Argos and Sparta, two most famous cities, once the lights of Greece, to besmirch in their slavery the title we have acquired from the liberated Greece?

The idea of the conquerors restoring ancient laws may sound innocuous, but it carries an echo of

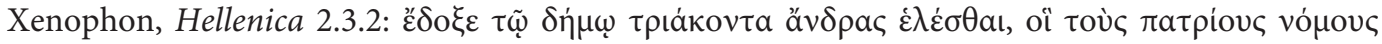

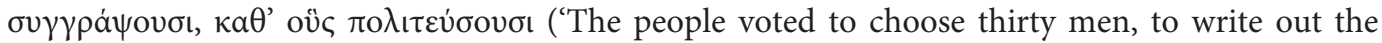
ancestral laws under which they would run the city'). The Thirty Tyrants, imposed on the city as rulers following the Spartan victory, likewise, in Xenophon's presentation, claimed to be restoring traditional laws-in this case returning Athens to its pre-democratic state. The Romans, once again acting in part on behalf of the Athenians, are planning to treat the conquered Sparta in a parallel fashion to the way that Sparta had treated conquered Athens.

Indeed, as Rome has moved into Greece and has engaged with the Greek past, in the manner set out in the first part of this paper, her primary identification has been with Athens. Rome is fighting for Athens, and the allusions to specific texts suggest a favourable comparison with Athens.

(19) See e.g. Thucydides 1.69.1 with Hornblower 1991, p. 113. 
That is perhaps unsurprising, in as much as the primary texts to which Livy alludes were written by Athenians and highlighted the Athenian perspective. So even when, as here, the Romans act as the Spartans had, it is not simply that their role has switched to being a Spartan one. It is still the case that the first point of reference is Athens, and the Romans' Spartan-like behaviour is ironically employed against Sparta. The Romans, in fighting Nabis are acting as quasi-Athenians who are replaying in reverse the role of Sparta in the Peloponnesian War; and this is suggested by a further echo of the events of that war. The other Greeks, pushing the Romans to war, are determined to have them depose Nabis, on the grounds that to leave him in power would be to strengthen him (34.33.8-9); the Romans, however, demur, arguing that to depose Nabis would require them to destroy Sparta entirely (34.49.2). ${ }^{20}$ A comparable debate occurred at the end of the Peloponnesian War (Xenophon, Hellenica 2.2.19-20): ${ }^{21}$

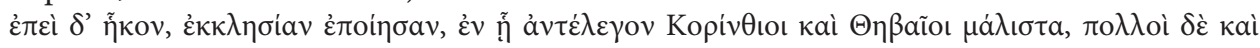

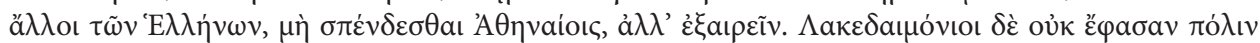

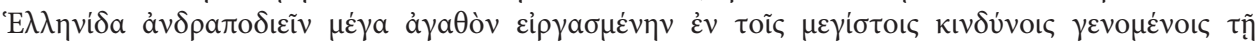

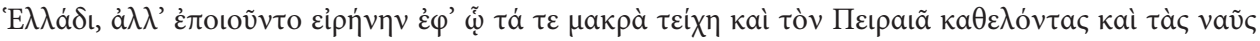

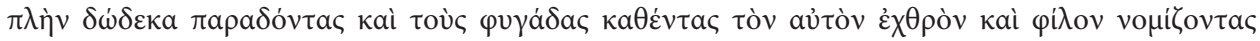

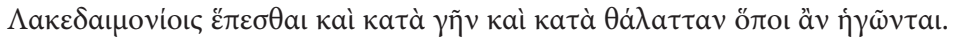

When they arrived, the ephors called an assembly, at which the Corinthians and Thebans in particular and many other Greeks opposed making a treaty with the Athenians and favoured destroying their city. The Spartans, however, said that they would not enslave a Greek city which had done great service amid the greatest perils that had befallen Greece, and they offered to make peace on these conditions: that the Athenians should destroy the Long Walls and the walls of Piraeus, surrender all their ships except twelve, allow their exiles to return, count the same people friends and enemies as the Spartans did, and follow them both by land and by sea wherever they should lead the way.

Effectively, the Romans have, on behalf of Athens, treated Sparta, for good and ill, in the way that the Spartans treated Athens at the end of the Peloponnesian War.

The story of Sparta in Livy does not, however, end with the war with Nabis. Sparta represents one of the relatively few places in Livy where he steps outside a purely Romanocentric narrative and offers an account of a largely non-Roman event: in this case the defeat of Sparta by the Achaean general Philopoemen in 188 B.C. (Livy 38.34.1-4):

hoc metu iniecto Lacedaemoniis imperatum primum, uti muros diruerent; deinde ut omnes externi auxiliares, qui mercede apud tyrannos militassent, terra Laconica excederent; tum uti quae servitia tyranni liberassent-ea magna multitudo erat-ante diem certam abirent; qui ibi mansissent, eos prendendi abducendi vendendi Achaeis ius esset; Lycurgi leges moresque abrogarent, Achaeorum adsuescerent legibus institutisque; ita unius eos corporis fore et de omnibus rebus facilius consensuros. nihil oboedientius fecerunt quam ut muros diruerent, nec aegrius passi sunt quam exules reduci.

The Lacedemonians were terrified by this episode; they were first ordered to destroy their walls; then that all foreign auxiliaries who had served as mercenaries under the tyrants should leave Laconian territory; then that those whom the tyrants had freed from slavery-a substantial number of people-should leave before a named date, and that the Achaeans would have the right to seize, remove and sell those who remained; the Spartans should repeal the laws and customs of Lycurgus, and use the laws and practices of the Achaeans-that way they would be part of a single body and would more easily reach consensus on everything. The Spartans did nothing more willingly than destroying their walls; they suffered nothing more bitterly than restoring the exiles.

(20) On this debate see Moreschini 1985, p. 35, who suggests that Livy uses it as a way of highlighting the moral inferiority of the Greeks by comparison with the Romans.

(21) For the dispute between the Spartans and their allies over the treatment of Athens, cf. also e.g. Andocides, On the Mysteries 142, On the Peace 21. 
Three of the conditions that Philopoemen imposed on Sparta-restoring exiles, destroying walls, and removing the constitution-are closely paralleled in the settlement Lysander imposed on Athens in $404:{ }^{22}$ indeed, Livy's language, with its reference to the eagerness for the destruction of the walls, seems to echo Xenophon's (Hellenica 2.2.23):

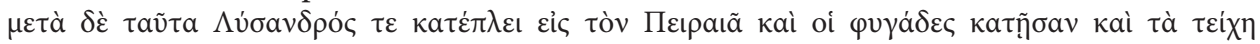

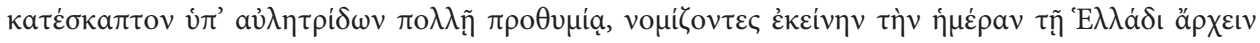

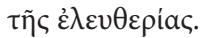

After this, Lysander sailed to the Piraeus and the exiles returned and they destroyed the walls with much enthusiasm to the sound of flute-players, thinking that this day was the beginning of freedom for Greece.

Of course, there is a substantial difference between the joy with which the walls are destroyed in Xenophon and that in Livy. In Xenophon, the enthusiasm comes from the enemies of the Athenian democracy, who see in the destruction of the walls the breaking of Athenian power and the end of the Athenians' capacity to oppress other Greeks. In Livy, it is the Spartans themselves who are enthusiastic to destroy their own walls, something that might appear paradoxical, except that, as Livy has previously noted (34.38.2), the walls were not a traditional part of the Spartan apparatus. It was the Spartan tyrants who had built the walls: prior to that, Sparta had been unwalled, and indeed Spartans took pride in the fact that they maintained their independence and power solely through their military prowess. Hence the destruction of the walls for Sparta, unlike that for Athens, could be seen as a restoration of Spartan power-were it not that at the same time, Philopoemen had removed the capacity for Spartan militarism that had traditionally protected Sparta in the absence of walls.

That paradox is, typically, one in which Livy takes a considerable interest-as always, he likes to focus on issues of moral and political ambiguity. He explores this one in greater depth in Book 39, where the Spartans appeal to the Romans, and they respond by remonstrating with the Achaeans over Philopoemen's actions (39.36.3-4):

Appius ea quae apud senatum questi erant Lacedaemonii displicere senatui ostendit: caedem primum ad Compasium factam eorum, qui a Philopoemene ad causam dicendam evocati venissent; deinde cum in homines ita saevitum esset, ne ulla parte crudelitas eorum cessaret, muros dirutos urbis nobilissimae esse, leges vetustissimas abrogatas, inclutamque per gentes disciplinam Lycurgi sublatam.

Appius revealed that the Senate was displeased with the matters on which the Spartans had complained to the Senate. First there was the murder at Compasium of the men who had come to defend themselves after being summoned by Philopoemen; then, after behaving so brutally towards people, the Achaeans, so as not to relax their cruelty in the slightest respect, had destroyed the walls of a most famous city, they had abolished their most ancient laws, they had destroyed the worldrenowned Lycurgan training.

However, on this matter the Romans do not have the final word. Instead, the Achaean spokesman Lycortas responds, noting the very point that was implicit in Livy's account of the destruction of the walls in Book 38: that the presence of walls at Sparta was a sign of Sparta's subjection to tyranny (39.37.1-6):

at enim illa certe vestra sunt, Achaei, quod leges disciplinamque vetustissimam Lycurgi sustulistis, quod muros diruistis. quae utraque ab iisdem obici qui possunt, cum muri Lacedaemoniis non ab Lycurgo, sed paucos ante annos ad dissolvendam Lycurgi disciplinam exstructi sint? tyranni enim nuper eos arcem et munimentum sibi, non civitati paraverunt; et si exsistat hodie ab inferis Lycurgus,

(22) The central symbolic importance of the destruction of the Long Walls at the end of the Peloponnesian War as a sign of the end of Athenian power is explicitly stated in Pоцүвгus 38.2.6-7, who also sees it as an oppressive overreach by the Spartans. It is, accordingly, possible that Polybius himself explicitly or implicitly pointed up the parallel when recounting Philopoemen's actions, and that Livy is drawing on that here. 
gaudeat ruinis eorum, et nunc se patriam et Spartam antiquam agnoscere dicat. non Philopoemenem exspectare nec Achaeos, sed vos ipsi Lacedaemonii, vestris manibus amoliri et diruere omnia vestigia tyrannidis debuistis. vestrae enim illae deformes veluti notae servitutis erant, et cum sine muris per octingentos prope annos liberi, aliquando etiam principes Graeciae fuissetis, muris velut compedibus circumdatis vincti per centum annos servistis. quod ad leges ademptas attinet, ego antiquas Lacedaemoniis leges tyrannos ademisse arbitror; nos non suas ademisse, quas non habebant, sed nostras leges dedisse.

"But it is certainly your responsibility, Achaeans, that you destroyed the laws and ancient training of Lycurgus, and that you demolished the walls". How can these charges both be levelled by the same people, since the walls were not erected for the Spartans by Lycurgus, but were built a few years ago for the purpose of abolishing Lycurgus' training? The tyrants designed them recently as a citadel and defence for themselves, not for the state. If Lycurgus were to rise from the dead today, he would celebrate their ruins, and would say that he now recognized his homeland and the Sparta of old. You, Spartans, should not have waited for Philopoemen or the Achaeans, but should have dismantled and destroyed all vestiges of the tyranny with your own hands. The walls were like ugly marks of your enslavement, and when you lived free without walls for almost 800 years, and had at times been the leaders of Greece, you were slaves for 100 years, chained by the walls which surrounded you like shackles. As far as removing laws goes, I consider that it was the tyrants who removed the Spartans' ancient laws. We did not remove theirs, since they did not have them; but gave them our laws.

The connection between the walls and slavery, and their destruction and freedom, once again recalls Xenophon, Hellenica 2.2.23 (quoted above, p. 75); it is moreover true, as noted already, that the walls were not traditional to Sparta, and indeed that they were arguably a symbol of Spartan enslavement rather than of Spartan freedom-hence the Spartans' own enthusiasm for their removal. However, Lycortas' argument-at least as Livy presents it - is partly disingenuous. He claims that the Achaeans had no part in the removal of the Lycurgan system, since the Lycurgan constitution had already been effectively abolished by the tyrants; but Livy has in his own voice given the lie to that when he described Philopoemen's Spartan settlement; moreover, even if it had been true, it would hardly justify removing the vestiges of the Lycurgan system. The speech in Livy is presumably based on something in Polybius, ${ }^{23}$ since Lycortas was Polybius' father and has a correspondingly substantial role in Polybius' history, but the subtle moral paradox that emerges from his speech is very typical of Livy. Sparta does indeed, at the hands of Philopoemen, find herself restored to the physical state associated with her power in the classical period; but she is also left in a state in which she is unable to take advantage of that. And indeed, in this respect, the Romans' expressed wishes do not prevail: Sparta remains a hollowed-out shell. It is worth noting in this context the description of Sparta during Aemilius' tour of Greece (45.28.4): inde Lacedaemonem adit, non operum magnificentia, sed disciplina institutisque memorabilem ('From there he went to Sparta, memorable not for the magnificence of its buildings, but for its discipline and institutions'). I have already noted above (n.1) the allusion to Thucydides 1.10.2, with the discussion of the difference between the physical grandeur of Athens and the less imposing buildings of Sparta; but there is a further aspect of what Livy says here that deserves consideration. While it may be the disciplina and instituta that made Sparta famous, Philopoemen had made it impossible for Aemilius to see them. ${ }^{24}$

(23) Compare Polybius' discussion of the corruption of the Spartan constitution in the decades culminating in the rule of Nabis (4.81.12-14; cf. 2.47.3); this supports Lycortas' claim that the Achaeans were not responsible for destroying the Lycurgan constitution, but it does not fit Philopoemen's settlement as described in Livy. It is altogether possible that Livy reproduced Polybius' account of Lycortas' argument, while changing the narrative in such a way as to undercut that argument.

(24) Cf. Levene 2006, p. 83. 
The Peloponnesian War is no more than a partial and occasional undercurrent to Rome's conquest of Greece, but the upshot of those allusions is consistent. Rome is the new Athens: she acts on behalf of Athens, first against Philip, then against Sparta, and is victorious both times, as the classical Athens was not. Moreover, as the new Athens, she inflicts a dramatic reversal on the Spartans, placing her in much the same position as Athens had been placed by the Spartans at the end of the Peloponnesian War. The Romans do not deliberately undermine Athens or Sparta-on the contrary, they fight on behalf of the first and try unsuccessfully to defend the national status of the second. But the overall consequence is that both Athens and Sparta are left as mere shadows of their classical selves, and Rome is the one political and military reality. I referred just now to Aemilius' tour of Greece after his final victory at Pydna. Livy's description of that tour has many ramifications, but not the least of them is that Aemilius, via his viewing of the Greek past, takes control of it on behalf of Rome. The reference to the missing disciplina and instituta of Sparta is just one example of this: Aemilius' visit in general is marked by the absence as much as by the presence of the things that made Greece famous at its classical height; ${ }^{25}$ and even when the Greek monuments are still available, they have to give way to the new centrality of Rome. ${ }^{26}$ It is not incidental that Aemilius' tour culminates with a visit to Olympia, where Aemilius' reaction to Phidias' great statue of Zeus is to treat it as if he were in the temple of Jupiter Capitolinus at Rome (45.28.6), something true of neither Polybius' (as far as we can tell from the surviving fragments: 30.10.5-6) nor Plutarch's version of the story (Aem. 28.2), where Aemilius not only admires the statue, but comments on its fidelity to Homer. Phidias' Zeus is reinterpreted in Roman terms: whereas in Polybius, Aemilius' admiration of the statue reflects his subordination to Hellenic culture, for Livy, Rome and the Roman Jupiter have taken the mantle of power. ${ }^{27}$

David S. Levene New York University ${ }^{28}$

\section{Bibliography}

Briscoe, J., 1973, A Commentary on Livy Books XXXI-XXXIII, Oxford.

Eckstein, A. M., 2006, Mediterranean Anarchy, Interstate War, and the Rise of Rome, Berkeley.

-, 2008, Rome Enters the Greek East, Malden.

Eigler, U., 2003, "Aemilius Paullus: ein Feldherr auf Bildungsreise", in U. Eigler, U. Gotter, N. Luraghi,

U. Walter (eds.), Formen römischer Geschichtsschreibung von den Anfängen bis Livius, Darmstadt, p. $250-267$.

Finley, M. I., 1962, “Athenian Demagogues”, Past \& Present 21, p. 3-24.

Harris, W. V., 1979, War and Imperialism in Republican Rome 327-70 B.C., Oxford.

Hornblower, S., 1991, A Commentary on Thucydides, volume 1, Oxford.

Jaeger, M., 1997, Livy's Written Rome, Ann Arbor.

(25) Cf. JAEGER 1997, p. 3: "Time may have increased the renown of these tourist attractions, but by placing consistent emphasis on their role as reminders of a lost and greater past, Livy's version of the tour indicates how far Greece has declined [...] Rome is now the cultural center of the world".

(26) See Eigler 2003.

(27) See Russell 2012, p. 161-163.

(28) My thanks to the participants in the Strasbourg conference, and especially to Edith Foster, for useful comments on this paper. 
-, 2010, "Once More to Syracuse: Livy's Perspective on the Verrines", in Wolfgang Polleichtner (ed.), Livy and Intertextuality, Bochum, p. 15-45.

Judeich, W., 1905, Topographie von Athen, Munich.

Levene, D. S., 2006, "History, Metahistory, and Audience Response in Livy Book 45", CA 25, p. 73-108.

-, 2010, Livy on the Hannibalic War, Oxford.

—, 2015, “Allusions and Intertextuality in Livy's Third Decade”, in Bernard Mineo (ed.), A Companion to Livy, Malden, p. 205-216.

Luce, T. J., 1977, Livy: The Composition of his History, Princeton.

Marincola, J., 2005, "Marcellus at Syracuse (Livy XXV, 24, 11-15): a Historian Reflects", in Carl Deroux (ed.),

Studies in Latin Literature and Roman History XII, Brussels, p. 219-229.

Moreschini, C., 1985, "Livio e il mondo greco", SCO 34, p. 27-57.

Polleichtner, W., 2010, "Fabius, Scipio, and the Sicilian Expedition: A Practical Lesson on Reading Thucydides", in Wolfgang Polleichtner (ed.), Livy and Intertextuality, Bochum, p. 67-92.

Pritchard, D., 2015, "Democracy and War in Ancient Athens and Today", Greece and Rome 62.2, p. 140-154.

Rodgers, B. S., 1986, “Great Expeditions: Livy on Thucydides”, TAPhA 116, p. 335-352.

Rossi, A., 2000, "The Tears of Marcellus: History of a Literary Motif in Livy", GઐR 47, p. 56-66.

Russell, A., 2012, "Aemilius Paullus Sees Greece: Travel, Vision, and Power in Polybius", in Christopher Smith and Liv M. Yarrow (eds.), Imperialism, Cultural Politics, and Polybius, Oxford, p. 152-167.

Stübler, G., 1941, Die Religiosität des Livius, Stuttgart.

Warrior, V. M., 1996, The Initiation of the Second Macedonian War, Stuttgart. 